\title{
Arbejdssamfundets svanesange. Refleksioner i anledning af Oskar Negt: Det levende arbejde, den stjålne tid
}

\author{
Hans Jørgen Thomsen
}

Som bekendt har det været den kapitalistiske æras civilisationshistoriske bedrift at organisere menneske- og samfundsliv efter arbejdslivets taktstok. Det kapitalistisk organiserede arbejde socialiserede menneskene, flyttede rundt på dem efter sine systemisk indbyggede imperativer, sløjfede byer og kommunikationskanaler fra landkortet for oprette sine egne - for så i en senere fase at sløjfe også disse, oprette nye osv. i en ustandselig strøm. Ved skånselsløst at nedskrive enhver tradition i fornyelsens og fremskridtets navn undergravede kapitalismen tilliden til en stabil menneskelig etos, og rastløshed (eller sociologisk neutralt: mobilitet) blev den socialisationshistoriske pendant til den kapitalistiske civilisations strømmen: i en selvbevægelig verden måtte sjælene uafladeligt være undervejs.

Først i den moderne verden er Heraklits flod blevet social realitet, og først her kan stilstand få chokkarakter, som i fotografiet. Når fotografiet virker chokerende på beskueren fra slutningen af det 19. århundrede, skyldes det, at det ved at fastholde $\varnothing$ jeblikket kommer til at virke som en opstand mod civilisationens strømmen. Der skal vane til at affinde sig med det kunstigt fastholdte sekund og opgive tanken om, at hér er noget galt. Som Benjamin anfører i sin aldeles genialske analyse af fotografiet, troede man spontant ved konfrontationen med fotografier af gadepartier i moderne byer, at hér var tale om afbildning af gerningssteder: først gentagelsen kunne aflive denne reaktion.

$\mathrm{Nu}$ har den historiske skabelse af en sådan strømmende og foranderlig verden ikke været nogen let sag. Især tilvejebringelsen af en arbejdsmoral - for arbejde var det jo, som hidførte de uafladelige forandringer - har kostet blod, sved og tårer. Max Weber har nok ret i at gøre netop indpodningen af arbejdsmoral til en afgørende forudsætning for opkomsten af kapitalismens foranderlige - og dog stadigt selvidentiske samfundssystem: uden kapitalistisk »ånd « ingen kapitalisme. Også Marx gjorde i sin polit $\varnothing$ konomiske systemanalyse opmærksom på de voldelige forudsætninger for at et selvregulerende system som det kapitalistiske historisk kunne opstå, nemlig i 1. Kapitalbinds 24. kapitel om »den såkaldte oprindelige akkumulation «. Med dette kapitels skildring af det kapitalistiske systems forudsætninger og mulighedsbetingelser har man holdepunkt for antagelsen om, at kortlægningen af det kapitalistiske systems reproduktionsog kriselovmæssigheder iøvrigt, dvs. resten af »Kapitalen «, strengt taget er en abstraktion, omend en fornuftig sådan. En abstraktion, hvis iværksættelse 
som realitet forudsætter »den såkaldte oprindelige akkumulations « historiske tvangsprocesser.

\section{Adskillelsesenergi, magt og civilisation}

Oskar Negt hører til de marxister, som fra første færd har været opmærksom på sammenhængene mellem vold, magt og så den kendte form for civilisation. Ikke blot har »den såkaldte oprindelige akkumulation «s terror været en central forudsætning for, at der overhovedet har kunnet opstå sådan noget som kapitalisme. Nej, terroren gentages overfor hver ny generation, som vokser op til at blive samfundsindivider. Magt og den stadige produktion af nye magtmekanismer er den usminkede baggrund, på hvilken de systemiske reproduktions- og kriselovmæssigheder alene virker.

Det hedder herom programmatisk i »Geschichte und Eigensinn«, som Negt udgiver i 1981 sammen med Alexander Kluge: »I modsætning til varerne $\mathrm{i}$ den materielle produktion af goder, i hvis resultat det frembringende arbejde forsvinder, forsvinder oprindelsesbetingelserne aldrig i varen arbejdskraft, i mennesket. 'Summen af alle døde slægter', konflikterne, men heller ikke historiens eller individualhistoriens lykkelige stunder - de forsvinder aldrig, men gentager sig ukueligt, indtil de er virkeliggjort på ny, dvs. indtil historie og livsforløb har opfyldt sig... Barnet svarer på urobjektet, det møder. Det lærer på sin egen måde, men ved at antecipere den anden. Det er betingelsen, hvorpå det forstår at adskille sig selv fra omverdensbetingelserne. Således lærer det 'at beherske sig'. Allerede hér har der fundet en række adskillelsesprocesser sted. Den alsidige aktivitet finder sin skranke i urobjekternes interesse, som ikke samtidigt retter sig mod alle barnets bevægelser, men imod dem, som dur til at sidde, stå og gå med. Barnet lærer at selektere sine bevægelser i dén af urobjekterne banede retning. Det vil dog ikke opgive, men inderliggøre lysten til alsidig aktivitet. Dette betyder: én del går til tilpasning, én del til protest. Dette arbejde produceres $\mathrm{i}$ adskillelsesprocessen fra alsidigheden. Michel Foucault betegner denne adskillelse, hvori livet fra starten geråder, som anstaltsformen... I alle disse afretninger, afspaltninger og overgange opstår nødvendigvis én del tilpasning, én del protest... Adskillelsesenergierne består objektivt af tabserfaring og i den subjektive evne til at svare herpå... Protesten som dén egenskabskæde, der er afspaltet fra realisering, besidder selvregulerende egenskaber. Alle senere tilpasningsydelser trækker ud af disse et stykke ligegyldigt men formålstjenligt ekstraarbejde. Omvendt går der tilpasningsydelser fra en tidligere adskillelsesfase ind i protesten på et senere tidspunkt, der endnu kun delvist trækker på disse tilpasningsydelser « (op. cit., Verlag Zweitausendeins, Frankfurt/M., s. 621-623).

Den adskillelsessammenhæng dvs. dét punkt, i hvilket den uendelige mængde adskillelsesenergier flyder sammen og trods alt konstituerer en strøm -, som bliver resultatet af kapitalismens ombrydninger i den menneskelige tilværelses fundamenter, indeholder irreversible træk ifølge Oskar Negt. Det er ikke muligt at vende tilbage til tilstanden før disse ombrydninger satte ind - det er ikke muligt »at vende tilbage til naturen«, som Rousseau i sin 
tid formulerede det og forestillede sig det muligt. Og selv om det skulle have været muligt, ville det ikke være $\emptyset n-$ skeligt, for de civilisatoriske adskillelsesprocesser er - ved siden af at være udbytnings- og undertrykkelsesprocesser - også differentierings- og mangfoldiggørelsesprocesser.

Magten er, som hos Foucault, civilisatorisk produktiv ifølge Oskar Negt: differentieringerne producerer historisk nye energier, og termen adskillelsesenergi er central $\mathrm{i} »$ Geschichte und Eigensinn«. Den benævner, at det afgørende ved de civilisatoriske adskillelsesprocesser ikke så meget er deres resultater, for de er nemlig - som alt i malstrømmen - foreløbige, men spændingsforholdene (eller energirelationerne) imellem de uddifferentierede enkeltmomenter. Det er fra relationelle spændingsforhold imellem civilisatorisk producerede - og som sådan principielt foreløbige - enkeltmomenter i samfundshelheden, at de enkelte uddifferentierede momenter får deres relative og provisoriske betydninger. Som i eksemplet ovenfor: tilpasningen er betydningsfuld ved de former for protest, den producerer, og protesten vinder betydning i kraft af de tilpasningskompetencer, den formår at bearbejde og eventuelt mobilisere.

Det kan lyde sofistikeret, men først og fremmest er det dialektisk, nemlig derved, at det ene ikke kan begribes uden ved og igennem sit andet - og vice versa. Og som dialektisk i dette ords egentlige betydning indeholder det da også et brud med indarbejdede tankevaner i megen borgerlig og (paradoksalt nok!) marxistisk teori, hvad jeg skal vende tilbage til.
Imidlertid kan man godt eksemplificere, hvad der menes, ved at trække et tilbagevendende tema $\mathrm{i}$ de negtske reflexioner siden »Offentlighed og erfaring « fra 1972 frem i lyset. I den videnskabelige bestemmelse af den samfundsmæssige produktion og reproduktion i moderne samfund er den vigtigste referent for bestemmelsen af hver af disse sfærer henvisningen til sfærens modsætning. Reproduktionssfæren er frem for alt bestemt ved IKKE at tilhøre produktionssfæren - og omvendt. Relationen til en anden sfære/andre sfærer er bestemmende for et givet samfundsmæssigt moment mere end momentets eventuelle egenlogik eller definition af og ved sig selv er det. Kort sagt: i et moderne samfund er dialektiske relationer samt energi- og magtforhold relationerne imellem af største betydning for helhedens stabilitet eller instabilitet.

Når og hvis en marxistisk teori indoptager sådanne tankefigurer, kan den komme på højde med sit tema, dvs.: sin tid. Hvis der nemlig er noget moderniteten - uafhængigt af enhver teori om den - gør ved det menneskelige og det samfundsmæssige, så er det at afskaffe substans- og essensbestemmelser som disse størrelsers grund. Det menneskelige samfund river sig med det moderne slet og ret løs (fri) af substantielle/essentielle begrundelsessammenhænge, og dette er en proces, der selvsagt også vedrører eksistensmåden for de enkelte momenter i den samfundsmæssige helhed.

$\mathrm{Nu}$ er der desværre en kritisk pointe i, sådan som Negt (og Kluge) siden »Offentlighed og erfaring « har bestræbt sig på, at føre marxismens teori ind i det emfatisk modernes problematik. Det er der, fordi marxismens historie - altså den marxistiske 
teoris historie - i høj grad har været, så at sige, tabt bagud af dansen i forhold til det modernes umiddelbart erfarede temaer. Den marxistiske teori har i sin ortodokse form haft travlt med at substantialisere sine kategorier op imod og i kontrast til modernitetens malstrøm, og den har derfor også måttet betale prisen: tiltagende mangel på troværdighed hos samtidssensitive intellektuelle samt hos de masser, hvis interesser den hævdede at varetage, men for hvilke de emfatisk moderne oplevelses- og tankemønstre i tiltagende grad blev selvfølgeligheder, der ikke kunne rokkes ved.

Et af de mest udbredte og konsekvensrige eksempler er substantialiseringen af kategorien: proletariat. Det er ikke tilfældigt, når Negt og Kluge i »Offentlighed og erfaring « tager sig for at aflive denne substans, der ikke alene har givet næring til så mange omvendterborgerlige intellektuelles selvplageri, men også har kostet så mange hoveder i socialismens navn: »De virkelige historiske udviklinger forløber ikke på det 'hele menneskes' og de 'hele proletarers' side, men på niveauet for deres enkelte egenskaber« (den tyske udgave af »Offentlighed og erfaring, edition suhrkamp, Frankfurt/M 1972, s. 485).

Sætningen står i et afsnit med den sigende overskrift: »Proletariatet som substans og som sum af egenskaber«, og intentionen er naturligvis at erstatte det første med det sidste. Imidlertid har konceptionen $\mathrm{i} \gg$ Offentlighed og erfaring « ikke helt sluppet substansbegreberne, hvilket især viser sig i begreber som »proletarisk blok af liv«, »materialistisk instinkt « m.v. Først »Geschichte und Eigensinn« maner substansspøgelset helt i jorden, hvilket viser sig i den afgørende kategori hér, kategorien adskillelsesenergi.

Imidlertid viser den aktuelle politiske og filosofiske konjunktur, at marxismen tilsyneladende af sin egen historie er blevet dømt til at leve videre i skyggen af denne. Hinsides det faktum, at de marxismer og dén kritiske teori, som i dag har noget at sige, har fordrevet substanstænkningen fra sine refleksioner - og heri adskiller sig fra den meste institutionaliserede borgerlige tænkning -, hinsides dette forfølges den kritiske teori stadig af den ortodokse marxismes blodplettede og ressentimentshærgede karriere i dette århundrede. Det er tilsyneladende muligt, med den aktuelle politiske vind i ryggen, at banke den marxistiske kritik tilbage i en substanstænknings-position og så - når dét er gjort - med gode argumenter at banke løs på denne. Er det første træk lykkedes, giver det næste nemlig sig selv: har man med held reduceret marxismen til en teori, som fortrænger modernitetens erosionsog nivelleringseffekter, er det ingen sag at tage livet af den, hhv. latterliggøre den.

Ikke desto mindre er det en (potentielt) renoveret marxistisk kritiks styrke, at den intenderer og har muligheden for at gennemføre opgøret med substanstænkningen uden at give afkald på et sådant opgørs civilisationsteoretisk brede forudsætninger og civilisationskritisk vidtrækkende konsekvenser. Det kan fastholdes, at det er moderniteten i allerbredeste og allermest differentierede forstand, som sætter kritikken af substanstænkningen på teoriens dagsorden. 
En sådan fastholdelse er nemlig ingen selvfølgelighed. Tværtimod viser det sig i den aktuelle konjunktur, at den meste kritik af marxismens påståede substantialisme kommer fra ret begrænsede kulturanalytiske eller-kritiske hold. Derved ses der bort fra, at (erfaringen og betoningen af) malstrømmen, det tilblivende og fluktuerende livs regelløshed, hører sammen med modernitetens civilisationshistoriske form. Denne bredde skulle nødig forflygtiges, når tidsdiagnosen stilles: tiderne er af lave, meningen en saga blot og den blotte eksistens det eneste, det ikke rigtigt giver mening at betvivle. Alt dette er ikke sager alene for sofistikerede eller særligt følsomme intellektuelle: det er alment gods i den moderne civilisation.

Sidste skud på den civilisationshistoriske erosionsproces' stamme er den påbegyndte erosion under arbejdssamfundets fundamenter. At en sådan erosion er indledt mener Oskar Negt, såvel som en André Gorz og en Jürgen Habermas mener det, og fortolkningen af denne erosion er temaet for »Lebendige Arbeit, enteignete Zeit« - en bog, Oskar Negt udgiver i 1984 foranlediget af den tyske, hhv. den vesteuropæiske arbejderbevægelses krav om en 35-timers arbejdsuge. Anstødssten er altså det kapitalistiske arbejdssamfunds krise, og Negt ville (sammen med Gorz) uden tvivl kunne skrive under på følgende almene udsagn fra Habermas, fremført i et foredrag holdt for det spanske parlament Cortes og siden trykt i »Die neue Unübersichtlichkeit«, edition suhrkamp, Frankfurt/M, s. 157 , med titlen »Die Krise des Wohlfahrtsstaates und die Erschöpfung utopischer Energien«: »Socialstatsudviklingen er kommet ind i en blindgyde, hvori energierne fra arbejdssamfundets utopi opbruges $\ll$.

Men dermed ophører så også enigheden mellem de tre indflydelsesrige tidsdiagnostikere. For at få det specifikke ved Negts interpretation frem, skal jeg opholde mig ved relationen mellem kategorierne erosion og mulighed, sådan som denne relation fremlægges i »Geschichte und Eigensinn«. De to kategorier hænger i dette værk sammen med en demonstrativ afsked med det historiefilosofiske paradigmes rolle i marxismen - og sådanne demonstrative afskedsscener findes hverken hos Habermas eller hos Gorz.

\section{Erosion og mulighed}

Ernst Bloch anfører et sted, at den hidtidige filosofihistories konsekvensrigeste undladelsessynd har været den manglende refleksion på kategorien mulighed. På trods af at modernitetens tumult burde sætte netop denne refleksion på dagsordenen, er man vidne til det modsatte: aldrig er der blevet talt (og gjort) så meget i nødvendighedens navn som efter at det moderne indledte sin undergravende virksomhed overfor samme. Sagen er imidlertid, at et emfatisk mulighedsbegreb implicerer destruktionen - eller med den hér valgte terminologi: erosionen - af nødvendighedsbestemmelser. Erosionen af nødvendighed er identisk med produktionen af mulighedsbetingelser. Dette gælder filosofisk, og det gælder historisk, hvad kapitalismens æra er eksempel på.

Sammenhængen mellem erosion og mulighed - er sammenhæng, der får social breddevirkning med kapitalismens historiske opkomst - betyder, at nuet bliver til et punkt, hvorfra det bliver muligt at se bagud (på det tabte 
land) og fremad (på det forjættede). Omkostningen er imidlertid, at nutiden bliver dunkel for sig selv - ligesom der er mørkt for foden af et fyrtårn. Blandt andet derfor bliver fravær og fraværsbestemmelser vigtige $\mathrm{i}$ et sådant punkt, og utallige af de bestemmelser som udkastes af den menneskelige erfaring i det, bliver betydningsfulde ved (ofte implicite) at referere til enten det tabte eller det forjættede land.

De stedfindende og stedfundne erosionsprocesser indeholder imidlertid så megen irreversibilitet, at dén civilisatoriske mulighed, som erosionen afdækker (og skaber) ikke kan tematiseres som en (gen)tilegnelsesproces i analogi med, hvordan den unge Marx forestiller sig, at det fremmedgjorte arbejdes produkter kan gentilegnes i og af kommunismen. Kommunistisk frigørelse kan ifølge Negt (og Kluge) ikke afhandles som en idealiseret og antropologiseret arbejdsfigurs (gen) tilegnelse af sit afhændede produkt. Nej, en eventuel (dvs. mulig, men ikke nødvendig) frigørelse må være en virkeliggørelsesproces med baggrund i de erosioner og afhændelser, som den kapitalistiske historie iscenesætter: disse kan ikke gentilegnes, men de kan - qua mulighedsbetingelser - danne udgangspunkt for noget helt tredje, noget emfatisk nyt.

I afsnittet med den uoversættelige titel »Der Satz vom eingeschlossenen Dritten« fra »Geschichte und Eigensinn « erstatter Negt og Kluge derfor tilegnelseskategorien med virkeliggørelseskategorien, idet de beskedent tilskriver Marx deres eget synspunkt: »Hos Marx hedder selvfremmedgørelsens og afhændelsens modpol virkeliggфrelse... De afhændedes fælles svar må rette sig imod noget andet end mod en gentilegnelse af det tabte, nemlig mod forandring af virkeligheden, altså mod noget tredje« (op.cit., s. 41 og 43-44).

Det moderne nu's fyrtårnsvilkår, dets umiddelbare dunkelhed for sig selv, som Bloch kalder det, er modernitetens form for tidsbevidsthed. Snarere end betoningen af selve nuets dunkelhed burde man måske betone, at dette nu's karakter er indicium på opkomsten af en emfatisk samtidsbevidsthed. Dvs. en samtidsbevidsthed, som er klar over sin betydning i kraft af placeringen imellem en uophæveligt tilbagelagt fortid og så en mulig fremtids potentialer. Habermas formulerer det sådan hér i forelæsningen »Das Zeitbewusstsein der Moderne und ihr Bedürfnis nach Selbstvergewisserung «: »Det moderne kan og vil ikke længere låne sine orienterende målestokke fra en anden epokes forbilleder, den må skabe sin normativitet ud af sig selv. Uden mulighed for at undslippe ser det moderne sig henvist til sig selv. Det forklarer irritabiliteten i dets selvforståelse, dynamikken i de indtil vore dage rastløst fortsatte forsøg på at 'klargøre' sig selv « (Jürgen Habermas, Der philosophische Diskurs der Moderne, Suhrkamp, Frankfurt am Main 1984, s. 16).

Problemet i dette citat er ikke diagnosen, men den antydede medicin: at det moderne som det skærpede nu's erfarings- og bevidsthedsform skulle kunne skabe sin normativitet ud og af sig selv og derved som Münchhausen trække sig selv op ad dyndet ved håret. Denne løsning er problemet i Habermas' projekt, og det overkommes ikke ved nok så komplicerede filosofiske analyser til begrundelse af en universel emancipatorisk moral og dennes 
uimodsigelighed. Sagen er, at en sådan eventuel uimodsigelighed intet han udrette mod eventuelle modgående historiske udviklingstrends i tiden, og dem vil jeg mene, der er en del af. Filosofiske almengyldigheder har aldrig styret historiens gang, og gør det heller ikke i dag.

Omvendt gælder Gorz' patentmodel heller ikke: den mikroelektroniske revolution fører ikke nødvendigvis til systemets sammenbrud, endsige til ét af to bestemte steder hinsides dette system. Det modernes nu indeholder et objektivt usikkerhedsmoment, der ikke ophæves ved nok så ihærdige besværgelser af det imponerende (i den eller anden forstand) ved de igangværende teknologiske innovationsprocesser i den industrialiserede verden.

Imod såvel en Gorz' profetisme, der kan forklare hans effekt hos mange hjemløse venstreintellektuelle, som imod en Habermas' filosofisme, der kan forklare hans begrænsede gennemslagskraft ud over snævre videnskabelige og filosofiske cirkler, slår Oskar Negt koldt, men ædrueligg $\varnothing-$ rende vand i blodet på sine læsere i bogen $»$ Det levende arbejde, den stjålne tid. De politiske og kulturelle sider af kampen for nedsat arbejdstid « (dansk fortrinlig - oversættelse på politisk revy, Kbh. 1985). Nu som før begrunder de livsverdensmæssige erosioner, som følger i kølvandet på kapitalistisk igangsatte teknologiske innovationsprocesser, en mulighed for noget helt tredje: »Hvis man tager udgangspunkt i den nuværende bevidsthed og den samfundsmæssige dynamik, så må den ledenorm, hvorudfra det kan afg $\varnothing$ res, hvad der er moralsk, og hvad der er umoralsk, hvad der er retfærdigt, og hvad der er uretfærdigt, formuleres ud fra samfundet selv. Kategorien den objektive mulighed forekommer mig at være afgørende for denne ledenorm. Til forskel fra rent subjektive $\emptyset$ nskeforestillinger betegner den objektive mulighed tillige hele den omkreds af midler, der produceres og faktisk står til rådighed med henblik på realiseringen af emancipatoriske mål. Det betyder med andre ord, at det er samfundets objektive rigdom, der er målestokken for, hvad der er historisk udviklende og hvad der er historiske forbrydelser, hvad der er moralsk og hvad der er umoralsk. I alle disse forhold drejer det sig udelukkende om en ansvarlighedsetik, om følgerne af det man selv gør og undlader at gøre. I et samfund, hvor rigdommen på produkter, på videnskabelig erkendelse, på mulighederne for at gøre afhængighederne subjektivt gennemskuelige, har nået et sådant omfang, at denne objektivt disponible rigdom selv er blevet et problem, er herredømme og undertrykkelse historiske forbrydelser og umoralske « (op.cit. dansk udgave s. 205).

Man bemærker, hvordan moralsnakken i dette citat beror på eksistensen af en mulighed for frigørelse, men også på muligheden for at knægte frigørelsen ved at bevare de civilisatorisk knæsatte prioriteringer, kapitalismen har skabt og siden reproducerer ved at belønne dem hos sine adepter. Situationens uafgjorthed, dvs. dens objektive mulighed, hvortil så svarer den skærpede samtidsbevidsthed, implicerer ifølge Oskar Negt den samfundsmæssige kamp for og imod den eventuelle realisering af muligheden, og denne implicerer så igen for teorien kravet om partiskhed. 
I denne konstellation, og alene heri, tilslutter Negt sig det bedste i den marxistiske ortodoksis teoritradition: »Sandhed og partiskhed er uadskillelige: selv de største sandheder udbreder sig ikke af sig selv, men kræver en målbevidst polemik tilspidsning og agitation - og det gælder med henblik på såvel de forhold, der skal bekæmpes, som de sammenhænge, der måtte sættes i offentlighedens søgelys, hvis de skal underst $\varnothing t t e$ den praktiske orientering mod en ny samfundsorden « (op.cit., dansk udgave, s. 14).

En sådan indplacering kan han foretage med sindsro, fordi han i sammenbringningen af kategorierne erosion og mulighed har umuliggjort en påstand om at han skulle være historisk determinist eller det, der var værre. Kapitalismen er ingen stor fremtidshistorie, men hvor den bringer fremskridt - f.eks. i form af teknologisk innovation - hviler dette næsten altid på $\varnothing$ delæggelsen af menneskelige livssammenhænge og livsmuligheder. Og sådan er det stadig: hvor kapitalismen vælter frem med sin nye teknologi under armen, efterlader den social elendighed og menneskelig tomhed bag sig. Kun kamp kan i praksis forpurre eller bare relativere denne djævelske enhed af fremskridt og repression, og kun partiskhed i teorien kan ved kritisk intervention stille sit pinlige spørgsmål til den éntydighed, hvormed kapitalismens fornuft foretrækker at præsentere sin civilisatoriske indsats.

Kun ved at understrege, at den retning imod frihedens rige, som kapitalismen stadig indeholder systemiske betingelser for, de facto bliver til introduktionen af nye fremmedgørelsesog repressionsformer, hvis den ikke imødegås praktisk og teoretisk - kun derved kan livtaget med det kapitalistiske fremskridt blive til fors $\emptyset \mathrm{g}$ med menneskelig frigørelse.

»Det levende arbejde, den stjålne tid « fors $\varnothing$ ger sig med denne vanskelige balancegang, og i det store og hele lykkes nummeret rent teoretisk set, hvilket jeg skal søge at vise i det følgende, ligesom jeg skal forsøge ganske kort at pege på et par problematiske aspekter ved det stort set vellykkede nummers teoretiske hjælpebegreber. Forinden dog en kort lille note: det generelle indtryk efter endt læsning af bogen er umiddelbart forstemmende, fordi Negt påviser, hvordan systemet indeholder strategier til destruktion af de frig $\varnothing$ relseschancer, det selv producerer. In casu: en generel nedsættelse af arbejdstiden som følge af mikroelektronikkens indførelse vil kunne indfanges ved, at den frigjorte tid for det første kombineredes med en flexibilisering af den tilbageblevne arbejdstid med solidaritetsnedbrydende konsekvenser for de arbejdende, for det andet kobledes sammen med en yderligere spaltning af samfundet i to realiteter, og endelig for det tredje ville den frigjorte tid kunne inddæmmes af et accellererende forbrug af kulturindustrielt differentierede konsumgoder, fra bipspil til en uendelighed af tv-programmer.

Ikke desto mindre tror jeg, at en sådan umiddelbar forstemthed giver Negts bog en større forbindelse til samtiden, som den tager sig ud for de fleste, der stadig har kontakt til projektet om en menneskelig frigørelse for alle, indbefattende skabelsen af en fri og rig individualitet. Jeg tror ikke, tiden er til euforiske prognoser, men omvendt mener jeg heller ikke, at det hjælper noget at søge at bevare forestillingen om 
frihedens rige ved alene at trække på apokalyptiske ditto. Netop frigørelsen af den kritiske teori såvel fra euforiens Scylla såvel som fra apokalypsens Charybdis forekommer mig at stå på dagsordenen, og hér har Negts bog vigtige bidrag at yde - og også i sin nøgternhed vigtige korrektiver at formidle til de udbredte former for kritik, der henter for meget krudt enten i eufori eller apokalypser. Skal lyset holdes tændt, må det skærmes af en rolig hånd.

\section{Negativ dialektik og politisk praksis}

Skærpet samtids- og nutidsbevidsthed hører det modernes epoke til som sådan, så det har ikke i denne epokes historie skortet på tærskelbevidsthed (en betegnelse jeg har hugget fra et foredrag, H-J Schanz holdt foråret 1985 om det postmoderne og det moderne med særligt henblik på Lyotard), altså oplevelser af at befinde sig $\mathrm{i}$ et betydningsfuldt skæringspunkt mellem fortid og fremtid. Som det er alle samtidssensitive bekendt, forholder det sig også sådan i dag. På trods af dén krisemæssighed, som tærskelbevidstheder er bærere af, så har dén slags historiske situationer i det mindste dét fortrin, at de sætter en særlig tyk streg under det generelle modernitetsvilkår, nemlig fremkomsten af nu'ets betydningsfuldhed.

Oskar Negt føjer sig med sin seneste bog ind i rækken af tænkere, der betoner den $\varnothing$ jeblikkelige krises nu som et chancens $\varnothing$ jeblik. Deri ligner han, som sagt, André Gorz og Jürgen Habermas, og han ligner dem også derved, at det foreliggende samfunds grundproblem hænger sammen med (påbegyndte eller fuldbyrdede) erosioner under det kapitalistiske arbejds- samfund og dets utopier. Hos Gorz tages denne erosion til indtægt for en antagelse af, at kapitalismen umuligt slet og ret: umuligt - kan fortsætte med at eksistere og derfor nødvendigvis vil blive afløst af det ene eller det andet; af »frihedens rige« eller et $\varnothing \mathrm{ko}-$ fascistisk terrorregime.

Habermas er knapt så drastisk og er da heller ikke blevet læst som nogen profet - i hvert fald ikke hvad angår hans nøgterne samtidsdiagnose, omend af og til hvad angår hans filosofisk begrundede kommunikationsteori. Habermas konstaterer den nævnte udtørring af arbejdssamfundets utopiske ressourcer hér ved enden af velfærdssamfundets civilisationshistoriske provisorium, og han beklager ikke denne udtørring, eftersom han heri ser chancer for sin kommunikationsteoretiske utopi, hvis begrundelse han så iøvrigt vier det meste af sit filosofiske krudt. Han er dog så meget af en kritisk dialektiker, at han ikke - som Gorz glemmer, at det er en indre logisk og historisk modsigelse at ville aflede frihed af nødvendighed.

Arbejdssamfundets krise er en krise, der vedrører dets utopiske ressourcer ikke per se en apokalyptisk dommedagssituation, hvor det kun kan gå én af to veje, sådan som Gorz udmaler situationen; en dommedagsstemning, han kun kan skabe ved at drive besværgende argumentatorisk rovdrift på den økologiske krises faktum. Dette træk ved, og denne stemning i, Gorz' tankestil i de seneste tre bøger kan forklare hans udbredelse og status som profet - hinsides dén inspiration, enhver samfundskritisk interesse kan hente hos ham -, men det giver ikke hans refleksion større videnskabelig, og næppe heller tidsmæssig slidstyrke. 
Oskar Negts holdning i den seneste bog kan derimod med ham selv, via Gramsci, karakteriseres som følger: »i teorien er jeg pessimist, i praksis optimist« (op.cit. dansk oversættelse s. 209). Pessimismen er imidlertid ikke verdensanskuelsesmæssig eller metafysisk, men hos Oskar Negt en velbegrundet skepsis overfor de aktuelle samfundsmæssige udviklingstrends, han analyserer: »ligesom Kant i sin tid talte om, at behovet for Gud ikke er noget bevis på hans eksistens, så må man også fastholde, at uanset hvor intense de følelser og behov, der indgår i længslen efter et nyt samfund, er, så er de ikke noget bevis for, at dette samfund må og vil komme. Historien ligner mere et ruinlandskab, oversået med knuste og afbøjede forhåbninger, end en kontinuerlig tidsfølge af projekterede og udvidede menneskelige målsætninger; den har, som erfarne historiefilosoffer med rette fremhæver, ikke været lykkens skueplads« (op.cit. s. 210).

Metodisk peges der hér på en dobbeltlogisk tilgang til kapitalistisk civilisatorik - med historisk inspiration fra Adornos »Negative Dialektik« -, som også for den aktuelle krises vedkommende vil gøre gældende, at »vold og emancipation ligger her så tæt på hinanden, at de kun kan adskilles gennem præcise konstellationsbeskrivelser« (op.cit., dansk oversættelse, s. 211). Imidlertid er synspunktet som nævnt ikke hos Negt basis for nogen verdensanskuelsesmæssig eller udviklingsteoretisk skepticisme. På det principielle - om man vil: metodiske - plan er synspunktet tværtimod forudsætningen for at bibeholde det moderne nu's chancekarakter: dets iboende åbenhed.
Først og fremmest har synspunktet dog for Negt en didaktisk og politisk flanke, hvor det gælder om at udpege betingelser for, at krisens åbenhed kan kæmpes i retning af emancipation. Derfor er »Det levende arbejde, den stjålne tid « et intervenerende kampskrift til underbyggelse af de tyske fagforeningers - anno 1984 - kamp for 35 timers arbejdsuge. Interessen er at pege på, hvilke kampmål, der må opstilles, hvis denne kamp skal føres igennem med retning mod emancipation, bestemt som menneskenes virkeliggørelse af de historiske muligheder for et lykkeligt og herredømmefrit liv. Menneskenes muligheder herfor er ifølge Negt vokset gigantisk, og de vokser fortsat enormt som følge af de igangværende teknologiske innovationer i den avancerede, industrialiserede verden; den mikroelektroniske teknologis anvendelsesmæssige ekspansion er den produktivkraftsmæssige betingelse herfor, og fagforeningernes kamp for 35 timers arbejdsuge et første adækvat skridt til indløsning af de lykkemuligheder, dvs. muligheder for fri tid i marxsk forstand, som denne produktivkraftsudvikling skaber.

Dermed er det imidlertid i en vis forstand også sagt: resten - og den væsentlige del - af Negts analyse gælder besindelsen på de hindringer for indløsningen af disse muligheder, som kampen for dem må se i øjnene for at have nogen chance. Systemet 'har nemlig lugtet lunten, som er antændt af den nuværende krises indre modsætninger, og det er allerede godt i gang med at slukke den. Nøgternheden i konfrontationen hermed bestemmer, hvilke overvejelser og træk, der skal til for at kvalificere kampen for de 35 timer i lyset af de objektive lykkemuligheder, som 
krisens nu indeholder. Hvis sådanne overvejelser ikke gøres, og hvis adækvate praktiske skridt ikke tages i konsekvens af disse overvejelser, ja så er der ikke noget i vejen for at systemets inddæmningsbestræbelser kan lykkes.

Den overordnede konsekvens af en vellykket inddæmning, som allerede toner frem i dag, vil ifølge Oskar Negt være »en opsplitning af samfundet $\mathrm{i}$ 'to virkeligheder' " (op.cit., dansk oversættelse, s. 36-113, især dog s. 61-73). Opsplitningen af samfundet $i$ to virkeligheder er en civilisationshistorisk (dvs. strukturelt ny) effekt af den igangværende kapitalistiske konjunkturkrise. M.a.o.: en eventuel overvindelse af konjunkturkrisen vil ikke ifølge $\mathrm{Negt}$ kunne ophæve opsplitningen af samfundet $\mathrm{i}$ to virkeligheder, hvorfor denne opsplitning under alle omstændigheder (inklusive et eventuelt nyt konjunkturopsving) vil fortsætte sit erosionsarbejde under arbejdssamfundet, dvs. et samfund, hvis entydige centrum er kapitalistisk erhvervsarbejde, lønarbejdet.

Som sekulart fænomen, der som antydet også anbringer en tikkende bombe under arbejdssamfundets utopiske ressourcer, viser opsplitningen $\mathrm{i}$ to virkeligheder sig $\mathrm{i}$ en kvantitativt tiltagende udgrænsning af samfundsindivider fra lønarbejdet. Arbejdsløsheden er kun det (delvis konjunkturelt betingede) ekstreme udtryk herfor: længere og længere uddannelser, førtidspensionering m.m. er andre udtryk for den samme (kvalitativt konjunkturuafhængige) tendens. Opsplitningen fører til en voksende sektor med såkaldt sort økonomi, men først og fremmest fører den til en dyster ødelæggelse af menneskelige udfoldelseschancer.
I et samfund, der tvangsagtigt binder udfoldelse til erhvervsaktivitet og til dennes refleks i fritiden, bliver den fri tid en forbandelse, fordi den udgrænser fra samfundsmæssig indflydelse og derfor ofte går hånd i hånd med en nedbrydning af den personlige identitet. På trods heraf er det et systemisk indbygget imperativ at $\varnothing$ ge den fra erhvervsarbejdet afkoblede livstid - målt samfundsmæssigt men naturligvis ikke individuelt -, og heri består muligheden, som tages op og bearbejdes politisk i kravet om nedsat arbejdstid. Kun kampen for nedsat arbejdstid kan få kontakt med udviklingens frigørende muligheder, vel at bemærke når og hvis den i sine krav på én gang indoptager alle samfundsindividers ret til en værdig tilværelse og samtidig relaterer kravenes almenhed til specifikke interesser, i hvilke der artikuleres former for praksis, der har frigjort sig fra erhvervsarbejdets tvangsstrukturering af det moderne liv.

Negt peger på to centrale felter, hvor menneskelig udfoldelse er ved at have løsrevet sig fra betingetheden af erhvervsarbejde, nemlig (a) folks måde/sted at bo på og (b) folks kulturelle behov. Det er derfor vitalt, at begge interessefelter og udfoldelsesmedier indoptages i fagforeningernes kamp for nedsat arbejdstid. Et forhold, der understreges af, at modparten allerede er gået i offensiven på begge områder for at anvende dem som brohoved for en $\emptyset$ get fragmentering af livsverdenen, for en forstærkelse af den sociale anomi.

Overalt gælder det for Negt om at gøre kampen for nedsat arbejdstid til en kamp imod virkelighedens opsplitning i to dele. En sådan kamp kan i dét 
perspektiv blive til den begyndende indløsning $\mathrm{i}$ to dele. En sådan kamp kan i dét perspektiv blive til den begyndende indløsning af de frigørelsespotentialer, som de kapitalistiske produktivkræfter - ikke mindst i fasen for den mikroelektroniske teknologis anvendelsesmæssige udbredelse muliggør, men ikke garanterer. Perspektivet er den organisatoriske og kampmæssige generalisering af disse potentialer, og det involverer et brud med en opsplittet virkeligheds $\varnothing$ delæggende konsekvenser for alle. Dette perspektiv er kritisk, og det implicerer konfrontation - med Gramscis term: bevægelseskrig, -, eftersom modparten er $\mathrm{i}$ færd med at udfolde sin inddæmmende fragmenteringsstrategi på alle felter, hvor den objektive mulighed titter frem.

En påbegyndt bevægelseskrig, og en sådan er i virkeligheden kravene om nedsat arbejdstid, er imidlertid også at se nederlagets mulighed i øjnene: ud af det hele kan mageligt komme et menneskeliv og et samfund, hvis groteskhed med hensyn til beskadigelser nok ikke er set før i historien; grotesk vil det være, fordi beskadigelsernes og forvrængningernes omfang vil svare omvendt proportionalt til, hvor nærliggende den objektive mulighed vil være.

I sit efterskrift til den danske udgave gør Oskar Negt opmærksom på, at dét kompromis, der i BRD blev det foreløbige resultat af kampene for 35 timers arbejdsuge i 1984, synes at $\emptyset$ ge fragmenteringen mellem arbejdsgrupperne og true solidariteten i kommende kampe: »I overensstemmelse med dette kompromis bliver der nu indgået overenskomster, der indebærer, at der inden for de enkelte virksomheder bliver fastlagt forskellig arbejdstider - med det resultat, at der dermed også institutionaliseres en slags intern konkurrence mellem de ansatte på den enkelte virksomhed. Nogle skal arbejde 39 timer, andre kun 37 - og det medfører uundgåeligt rivaliseringer og social misundelse. Det var oprindelig et led i arbejdsgivernes kampstrategi at få netop dette mål opfyldt; arbejdstiden skulle fleksibelt rette sig efter produktionens krav, hvorved enheden mellem de ansatte på den enkelte virksomhed ville blive sprængt.

Når jeg taler om, at dette kompromis har medført vanskeligheder for fagforeningerne, så tænker jeg på det forhold, at fagforeningernes aktionsradius nu igen i langt højere grad er blevet presset tilbage til den virksomhedsnare overenskomstpolitik - og dét i en situation, hvor den kroniske krise i sig selv tværtimod kræver, at fagforeningerne udvikler en strategi, der forpligter sig på hele den samfundsmæssige udvikling. $\mathrm{Nu}$ bliver der fremover helt forskellige arbejdstidssystemer på de enkelte virksomheder. For de ansatte arbejdere kommer det bl.a. til at betyde, at den tid, de tilbringer på arbejdspladsen, vil være forskelligt struktureret, og at de selvfølgelige kontakter, der har været en følge af den fælles arbejdstid, nu vil blive brudt op og fragmenteret « (op. cit., s. 242-243).

\section{To afsluttende bemærkninger}

Det ovenstående har langt fra været inde på alle sider af »Det levende arbejde, den stjålne tid «, der hermed være anbefalet enhver, der fornemmer fragmenteringen af bevidstheden som et truende nederlagssyndrom. Oskar Negt er både filosof og sociolog, både 
utopiker og realist, både varm og kold. Det taler for tidens ugunst, hvis dette hindrer hans seneste bog $\mathrm{i}$ at få den udbredelse, den fortjener.

Jeg skal afslutningsvist pege på to temaer fra bogen, som er opmærksomheden værd, og som ikke har været nævnt ovenfor. Det drejer sig om (a) Negts filosofiske vurdering af arbejdsbegrebet og (b) hans sociologiske og socialpsykologiske omtale af »aspekter af teknikkens politiske psykologi

(a) Bestræbelsen for at extrahere en utopisk kerne af arbejdsbegrebet er permanent til stede i Oskar Negts civilisationskritiske forfatterskab, og det genoptages i den seneste bog under overskriften, hentet fra Marx' »Kritik af Gothaer Programmet«, »Arbejde som et livsbehov « (op.cit. s. 157-210). Udtørringen af arbejdssamfundets utopiske ressourcer og erosionen af erhvervsarbejdets socialt overgribende status anfægter ikke for Negt gyldigheden af den marxske utopis lancering af »arbejde som livsbehov«. Arbejde kan godt være centrum såvel for arbejdssamfundets iscenesættelse af kapitalistisk udbytning og undertrykkelse som for et kommunistisk samfunds frie menneskelige praksis. Er der ikke tale om en modsætning? Jeg vil mene: jo!

Når arbejdssamfundets svanesange sætter ind, anfægter det gyldigheden af arbejde som filosofisk grundkategori for et eventuelt alternativ - vil jeg mene. Oskar Negt er klar over problemet: »Men hvis nu erhvervsarbejdet fremover får en underordnet betydning i menneskenes livsproces, hvorfor er det så ikke desto mindre alligevel meningsfuldt at holde fast ved arbejdsbegrebet? Med rette kan man spørge: Når nu det traditionelle erhvervsarbejdes omfang svinder ind, hvad hindrer os så $\mathrm{i}$ helt af ofre dette i sin kulturelle betydning udhulede arbejdsbegreb og i stedet vælge begreber, der har en større historisk sensibilitet $\mathrm{i}$ forhold til nutid og fremtid og en anderledes analytisk rækkevidde? Disse spørgsmål er ikke så ligetil at besvare« (op.cit., s. 156).

Når Negt ikke desto mindre vil bibeholde arbejdsbegrebets centralitet for en utopi, anfører han forskellige grunde. Ethvert menneskeligt væsen betones således med rette - har behov for en objektiverende, tilegnende og modstandsovervindende omgang med et stykke objektivt første eller anden natur: det kan iagttages hos det lille barn, hvor det fører til patologi at hindre kontakt med ydre genstandsmæssighed. Civilisationshistorisk anfører Negt, at selv om det døde arbejde i form af praktisk træghed har fjernet sig radikalt fra en håndværksmæssig subjekt-objekt logicitet, så gælder det stadig - ja, som aldrig før -, at det selvstændiggjorte brugsværdikompleks $\mathrm{g} \varnothing \mathrm{r}$ krav på menneskelig opmærksomhed og menneskelige indgreb for at hindre udartninger i kontrafinalitet eller tilbagefald i entropi.

Endelig føjes de to markeringer sammen i følgende overvejelse: »Efter at den menneskeligt producerede objektverden er blevet en magt, der har sin egen lovmæssighed, kan man ikke lade som om man kan trække sig tilbage til et blot anskuende og nydende forhold til denne objektivitet. Det ville ikke blot være et tab af kontrol med den ydre objektverden, men det ville også betyde en udtømning af subjekterne. Som forgængelige væsener er de tvunget til at udarbejde sig i forhold til 
genstande, og det kan man kun gennem genstandsmaessig aktivitet, altså gennem arbejde « (op.cit. s. 162).

På trods af det indlysende rigtige i disse markeringer, rækker de i mine øjne ikke som argument for opretholdelsen af arbejdskategorien som utopiens kernebegreb. Hér mener jeg, Habermas gør ret i at pointere handlingskoordinering som et nyt afgørende problemfelt, ja kerneområde, for menneskelig praksis. Det er et område, som dukker frem med voksende prægnans netop som en konsekvens af det moderne brugsværdikompleks' tiltagende kompleksitet og interne differentieringer. Orientering og indgreb heri påkalder sig stadigt mere differentierede handlingskoordineringer samfundsindividerne imellem, og disse vil derfor naturligt lægge beslag på en voksende del af den menneskelige praksis. Dette gælder allerede, altså under den fortsatte udbytning og undertrykkelses herredømme, men det gælder så sandelig også utopisk. Hér forekommer arbejdskategoriens indelukkethed i subjektobjekt logiciteter restriktiv.

Kort sagt, og uden at abonnere på de sprogfilosofiske og evolutionsteoretiske indpaktninger, hvori Habermas serverer praksis som handlingskoordinering, så finder jeg denne udbygning og forskydning i kategorien for samfundsmæssig praksis på højde med sin tid, altså aktuelt og utopisk relevant. Den når mere af moderne menneskelig aktivitet end et nok så moderniseret arbejdsbegreb formår.

(b) Oskar Negt beskæftiger sig ikke synderligt med de igangværende teknologiske innovationsprocessers indholdsmæssige strukturer. I modsætning til en Gorz (såvel som til en Hoffmeyer) går han ikke fra teknologiernes formåen til deres sociale implikater og potentialer, men den omvendte vej. Ud fra den kritiske teoris socialvidenskabelige skepsis med hensyn til de aktuelle sociale og politiske forandringsprocesser, interesserer Negt sig for, hvordan teknologien og den teknologiske innovation fungerer hér: »Pseudo-konkrete forklaringer og undvigelsesman $\phi v r e r$ er ikke ualmindelige, når det gælder om at forklare og forstå ens egen misere... Disse undvigelsesman $\phi v r e r$ følger alle det samme princip, idet de udsøger sig en anonym ophavsmand eller årsag. $O g$ intet andet af den menneskelige kulturudviklings produkter er så velegnede som overføringsobjekt for dette aflastningsфnske som teknikken.

Det er karakteristisk for den nuværende krisesituation, at de nye teknologier nærmest udfører et gratis ekstraarbejde for det bestående herredømmesystem. Gennem deres blotte eksistens styrer de menneskenes angstreaktioner, der kan have en vidt forskellig oprindelse, de letter en proces, hvor disse angstreaktioner bindes, forskydes og neutraliseres « (op.cit., 212-213).

Negt markerer med denne erkendelsesinteresse, som dårligt mere end markeres i bogens afslutningskapitel, hvad der burde være et centralt tema for analysen af teknologi og teknologisk innovation i moderne kapitalistiske samfund: altså analysen af, hvorledes de sociale betydninger, som tillægges den teknologiske innovation, cirkulerer og produceres samfundsmæssigt - ikke mindst med henblik på at yde »et gratis ekstraarbejde for det bestående herredømmesystem «. En sådan analytik kræver selvsagt en socialvidenskabelig og humanistisk kompetence, der ikke kan sælge sit autonomt tilkæmpede kritikperspektiv til teknikkens materielle 
indholdsstrukturer, men endda vil holde på, at en del teknikkens indholdsside er medbestemt af den sociale formside.

Udbygningen af sådanne erkendelsesperspektiver er det selvstændige bidrag, som en kritisk social- og humanvidenskab har mulighed for at bringe med sig, når nye tværvidenskabelige discipliner mellem de traditionelle hu- man- og socialvidenskaber på den ene side og de traditionelle naturvidenskaber på den anden side bringes på bane. Det taler ikke for tidens gunst, hvis disse tværvidenskabelige nyskabelser kun kan realiseres, såfremt kritikdimensionen opereres bort fra socialog humanvidenskabernes kompetencekorpus.

Kurasje har tidligere bragt følgende artikler af Hans Jørgen Thomsen:

»Historiske forbemærkninger til rekonstruktion af en hegemonial marxisme«, i nr. 26, 1980.

$\gg$ Firserne - befrielse eller undergang?«, i nr. 30, 1982.

»Det uendeligt store i det uendeligt små«, i nr. 32, 1983. 